\title{
THE ROLE OF POLICE IN PROTECTION OF CRITICAL INFRASTRUCTURE IN THE REPUBLIC OF MACEDONIA
}

\author{
Tony Stankovski, Ph.D \\ Ministry of Interior \\ E-mail: stankovskitoni@yahoo.com
}

\begin{abstract}
Police as a state body is responsible for the protection of life, personal safety and property of citizens, maintaining a stable security situation, maintaining public law and order and law enforcement. Police, despite all the duties and powers by law also takes measures for protection of certain persons and facilities.

The constant and rapid changes due to globalization lead to increased security risks and dangers and in that way the global security picture becomes complex. In connection to that critical infrastructure (vital state infrastructure facilities) gets new dimensions and increased importance at national and international level. Because critical infrastructure is an important segment of national security, its protection must be continually developed, and is one of the main security priorities of each country.

Measures and activities for providing protection are taken by the police individually or in conjunction and cooperation with other authorities, organizations, legal entities and individuals, all within its competences and powers defined by the law. The emphasis should be put on the field of cooperation with private security, especially about the continuous exchange of data and information, which largely can improve identification and prevention of possible threats.

The entities responsible for the protection of critical infrastructure need to constantly upgrade their facilities to monitor the situation and assess the level of safety of the facilities and the readiness of personnel protection and rapid response to deal with risks and dangers targeting critical infrastructure. The facilities will be safe if all the necessary measures in the area of prevention and early warning are taken timely.
\end{abstract}




\section{Securiagues rity}

The successful protection of critical infrastructure is possible only by increasing cooperation and by continuously enhancing the performance of the police and private security.

Keywords: police, private security and critical infrastructure protection

\section{INTRODUCTION}

Police is part of the Ministry of Interior in which police affairs are performed by police officers. Police affairs are actions of police officers concerning the protection of life, personal safety and property of citizens. ${ }^{260}$

This duty is contained in the provisions of the Law on Police and in by-laws in which security of persons and facilities are further defined such as a Regulation on the security for persons and the facilities, the types of measures and activities and levels of security. ${ }^{261}$

Security of persons and objects in the sense of this means planning, organization, coordination and execution of operational-preventive and preventivetechnical, physical, health and other measures and actions aimed at providing security for:

$>$ The seats of state bodies and the space around them, as well as residential and representative buildings and the surrounding area that belongs to the state authorities of the Republic of Macedonia (Parliament, Government, ministries, residential and others);

$>$ Foreign diplomatic offices in Macedonia and their residences and international missions based in the Republic of Macedonia;

$>$ Facilities and spaces that are of particular importance and interest to the security and defense of the Republic of Macedonia (structures of the Ministry of interior and other buildings such as the State Archive of the Republic of

\footnotetext{
260 "Police Law", Official Gazette no. 114/06, Art.5

261 "Regulation on the protection of persons and the facilities, the types of measures and activities and levels of security", Official Gazette no. 56/14
} 
Macedonia, the Archive of the City of Skopje, the National Bank of Macedonia and other facilities of importance for security and stability of the country). ${ }^{262}$

Measures and activities for providing police protection are undertaken alone or in conjunction and cooperation with other authorities, organizations, legal entities and individuals, all within its competences and powers defined by law. The police need to strengthen cooperation with the private security especially in the exchange of data and information. This multidisciplinary approach is the only way we can meet the challenges that every day we have the opportunity to observe and feel in the immediate and wider environment (terrorist acts and threats of terrorist attacks on soft targets).

Although critical infrastructure in the country is a relatively new field, we can rightly say that the protection of buildings of special significance exists and is legally regulated before the Law on protecting people and property, then in the Law on private security. Namely, these laws provide that the Government determines which legal persons shall have the security of persons and property for their own needs, if the performance of their activity is associated with handling radioactive substances or other dangerous substances for people and the environment, objects and buildings of particular cultural and historical significance, and in other cases when it is in the interest of safety or defense of the Republic of Macedonia.

Because critical infrastructure is an important segment of national security, its protection must continually evolve and improve and should represent a major security priority of each country. This became particularly evident after the terrorist attacks in the United States since September 11, 2001.

The identification of risks and hazards and the timely response is an important factor for enhancing the security of critical infrastructure. A major component in the infrastructure security is the state's ability to detect, investigate and prevent security threats such as terrorism, organized crime, war, environmental, cyber and other types of threats.

The emphasis should be put on the field of cooperation and continuous exchange of data and information that will greatly help to identify and prevent possible threats, especially in the context of the concept of collective security.

262 "Regulation on the protection of persons and the facilities, the types of measures and activities and levels of security", Official Gazette no. 56/14 art.23 
The entities responsible for the protection of critical infrastructure need to constantly upgrade their capacities for surveillance and assessment of the level of safety of the facilities and the readiness of personnel protection and rapid response to deal with risks and dangers targeting critical infrastructure.

No facility or object that falls within the critical infrastructure should not be considered immune from attack, because all objects (the ones owned by the state government and those privately owned) represent potential targets.

The facilities will be more secure if all the necessary measures in the area of prevention and early warning are taken in timely manner.

Rapid processes of globalization in the world, despite its main feature - the constant and rapid changes brought negative consequences, such as: increase in safety risks and hazards, among other things, and they can relate to the economy, transport, health, energy, communications systems, information networks or, simply, everything that falls within the so-called critical infrastructure.

The term critical infrastructure usually refers to physical facilities / buildings, networks or organizations whose destruction or failure can cause partial or permanent damage to the social and economic life.

Different authors and relevant authorities related to this issue identify a wide range of economic sectors that fall under this definition, namely: energy, water and food, management of waste/materials, key transport networks (airports, railways, highways), financial institutions, banks and savings banks, health services and public safety organizations. ${ }^{263}$

Here, in Macedonia critical infrastructure is a relatively new concept and one that essentially means "value or set values and goods that are essential to the economy, state and society, often identified as a complex material and immaterial systems, whose disorder functioning or destruction could cause long-term harmful effects on the fundamental values of the economy, state and society in general. ${ }^{264}$ This determination corresponds conceptually with more established definitions of modern

${ }^{263}$ Critical Infrastructure Security and Protection, The Public-Private Opportunity, White Paper and Guidelines by CoESS, December 2010, p.5

264 "Legal framework for the provision of critical infrastructure, focusing on the provision of critical infrastructure in the country," Chamber of Macedonia's private security Stead graphics, Skopje 2016, p.9 


\section{Security}

states with more experience and expertise in the analyzed area. Thus, critical infrastructure provides: ${ }^{265}$

- In the United States - „essential services which represent support for American society and serve as a backbone or a pillar of the national economy, safety and health";

- In Canada - „processes, systems, facilities, technologies, networks, goods and services vital to the health, security, safety and economic well-being of citizens and the effective functioning of government";

- In the UK - "funds, facilities, systems, networks or processes and essential workers who manage and maintain the same, where their loss or disruption in the operation may result in large, harmful impact on the availability, integrity and performance of essential services including the services whose integrity, in case it is damaged, it could result in substantial loss of life, i.e. victims taking into account the significant economic or social impact and/or significant impact on the national security, defense or functioning of the state ";

- In Italy - "facilities, systems, networks and functions - physical or virtual, that are vital to the survival of the state, whose incapacitation or destruction would have a debilitating impact on security, national economic security, public health or safety, or any combination of these phenomena."

Not just above mentioned, but a number of other countries, members of the European Union and those outside of it, have paid careful attention and developed many programs, policies and manuals, guidelines and procedures for the protection of critical infrastructure. Some of these directives or initiatives that fall within the scope of determining the legal framework for improving the security of critical infrastructure are the following: ${ }^{266}$

- In 2008, the EU Directive on the identification and designation of European Critical Infrastructure and the assessment of the need for improvement of protection lapplies to energy and transportation sectors, and provides owners/operators of critical infrastructure to prepare a security plan and appoint licensed security officer).

\footnotetext{
265 Ibid, p.10-12

${ }^{266}$ Ibid, p.24-25
} 
- In 2012, the Confederation of European Security Services (CoESS), prepared a white paper titled "Protection and security of critical infrastructure - publicprivate opportunities" (analyzed this issue in terms of private and public entities and suggests explicit division the roles and responsibilities).

- In 2013, a document audit of the European Program for Critical Infrastructure Protection (based on the practical implementation of activities such as prevention, preparedness and response).

- In 2013, we designed portal "Network Information Warning Critical Infrastructure (CIWIN)", to raise awareness about the same.

Our neighbor Serbia, has developed Guidelines for the methodology of assessing the threat of plans for protection and rescue of ten sectors of critical infrastructure. The essence of this Guide is based on the sources of danger and consequences which distortion and disruption of the functioning of the infrastructure might have on the economy and the environment. ${ }^{267}$

In Macedonia, however, in the National Concept for Security and Defense, protection of vital infrastructure ranks as one of the vital interests that promote the security and that creates conditions for better life of citizens and the functioning of the state and society. ${ }^{268}$ However, it must be noted that public security sector is still in the phase of reforms, despite having already drawn up and having existing legislation in the area of critical infrastructure, further efforts for more comprehensive legal framework regulation of this issue must be taken and there is a need for existence of a clearly defined framework for defining, identifying and protecting it.

267 "Legal framework for the provision of critical infrastructure, focusing on the provision of critical infrastructure in the country," Chamber of Macedonia's private security Stead graphics, Skopje 2016, p,35

268 "National Concept for Security and Defense," Official Gazette of RM no. 40/03, p.3 


\section{THE ROLE OF POLICE IN PROTECTION OF CRITICAL INFRASTRUCTURE}

\subsection{Measures and activities for protection of persons and facilities}

Any natural disaster or outbreak, whether derived from nature as a dangerous condition or hazard that is created as a result of an action of the people and that threatens the security and reliability requires attention and appropriate action and reaction. Security issues are normally managed by the government institutions, administrative departments, NGOs and other professional associations, but recognizable and timely accountability of course is still in the hands of authorized officials. Police in this context, in modern democracies still transforms its role in the new environment and searches for the model of its essence. Recent habits for the view of the police expectations significantly affect both the communities and the police concepts, programs, organization and system. Police in our country accept modern standards, while at the same time consolidates and projects internal capacities, resources, programs and strategic priorities for action and more efficient operation, unburdened by political discourses. Since the ultimate goal of the police is to be aimed at all citizens and their protection, and the protection of national security, it shows about the complexity of the role of the police as well as the complexity in the relationship with other stakeholders responsible for national security.

The current environment of globalization and unstoppable process of farreaching, geo-climate, socio-political, economic, social and other changes, causes concern in large-scale racial, religious, national, cultural, ethnic and other conflicts. They unfortunately, despite all the efforts for their eradication, continuously generate new forms of terrorism, violence and crime in all spheres of our daily living.

Particularly disturbing are frequent and strong mutually logistical, and often operative or action based interconnection between various organized groups or organizations that connect together and provide firearms, explosives, counterfeit identification and accreditation documents and money, operationally relevant information and others. resources and services of skilled counterfeiters, arsonists, chemists, electronics experts, plastic surgeons, smugglers, hackers and others that allow the success of their criminal operations and survival of their organizations.

On the other hand, each individual has a unique need for security and safety. These are objectives that weighs each country take care to protect their citizens and 
property, whether it is a private property, or national good. Each state has actively taken measures and actions to prevent all phenomena of above listed modern forms of danger, from regulation of its legislation to act preventively, proactively and repressively towards the perpetrators of such acts. This segment of protection and security policy includes the judiciary, police, military, security, intelligence, customs inspections and the entire private protection sector. Series of measures and activities prescribed in the law are being taken regarding the protection and security of persons and facilities by authorized personnel engaged. They relate to the detection and prevention of illegal actions against persons and facilities provided, but also extend to ensuring the personal security of individuals and facilities, material goods and property is protected.

These measures are taken in case individuals or groups and foreign intelligence services hostile directed against our country plan to endanger the safety of persons, property and material goods to be supplied or, in case such actions to be brought to endanger public safety of our highest government officials, foreign dignitaries, diplomatic and consular missions and international missions.

Authorized officials take security measures and activities in cases of natural disasters (earthquakes, floods, fires and other natural and unpredictable forces) that can affect the damage to buildings and endangering the safety of persons and other persons present in buildings and the spaces provided.

Measures and activities for securing persons and facilities consist of taking:

- Operational and preventive measures and activities for protection of persons, objects and spaces;

- Preventive technical measures and activities for protection covering mechanical, electronic, technical, anti-diversion, chemical-biological-radiation, sanitary and health, fire and other types of protection of persons and facilities;

- Physical and traffic protection of facilities and persons;

- Monitoring of the actions and activities of general measures and activities for providing the state authorities and other entities in the interest of the security and defense of the Republic of Macedonia managed by entities acting as legal entities, each within its jurisdiction and powers defined by law;

- Other necessary measures and activities of interest and importance to protection of persons and facilities. 
Of particular importance is the above measures to be taken based on planning and communication, dialogue and mutual trust between the entities responsible for the protection of critical infrastructure.

\subsection{Measures to strengthen the level of protection of facilities}

In order to strengthen the level of protection of objects it is necessary to continuously strengthen the capacities of entities responsible for their protection and in the area of monitoring and evaluation, planning, coordination and control of the measures taken. Many objects of critical infrastructure have been already covered by various systems of organization of physical and technical protection, but in the future you have to expect even more quality approach, every owner or manager of the facility of critical infrastructure will have among other things to make a safety plan that will be reviewed by the Ministry of interior. That plan would enable quick and appropriate response to any threat. Of course, one has to work on the preparation of training, which will be designed in a way to enable the persons responsible for providing rapid and appropriate response to the threat, (success in dealing with the threat depends on the initial response to the threat) or to demonstrate they have met organizational expectations. Finally, we should not forget the need for increased cooperation and support of all stakeholders involved in the protection of facilities of vital importance. That cooperation primarily relates to exchange and share information and concrete support in taking measures and activities in the provision of facilities.

In the area of exchange of information, the planning of exchange of information is crucial. This will strengthen national and international mechanisms for the exchange of information, planning and operational coordination, which represents support security in the country (eg. aviation and border crossings, protection of the critical infrastructure), risk prevention, risk reduction, strengthening legislation and combined operations. ${ }^{269}$

Mutual cooperation and support - protection of facilities of vital importance during a critical incident is an interagency and multidisciplinary.

269 NATO Workshop in Brussels, "Development plans for inter-institutional exchange of information security in the country", 2011-04-09, http://mail.cuk.gov.mk/index.php?arhiva=1\&content=354, accessed 25.01.2016 year 
Measures and activities for protection of the facilities, taken by the responsible persons, on which successful execution depends are:

- Evacuation or shelter in a safe place;

- Protections of the scene;

- Access control of entrances and exits;

- Providing seamless access and exit for vehicles for providing emergency medical assistance, fire fighting vehicles, etc.;

- Coordinated occurrence and management;

- Determination of a sufficient number of security personnel;

- Establish an appropriate system for communication;

- Exchange of information as a key segment in handling incidents.

\subsection{Jurisdiction of the police in the monitoring and supervision of private entities working in private security sector}

Authorized officials of the Ministry of Interior are responsible for supervising the implementation of the Law on Private Security and the regulations made under this Act.

Minister of interior establishes a committee for supervising of the work of the Chamber and legal entities of private security which is composed of a president, three members and their deputies. The Commission is tasked to issue and revoke licenses for the operation of legal entities registered for performing private security activity and to control and supervise the work of these entities registered for private security in the form of providing services for their own needs. Commission acts upon written notices received from the Sector for internal affairs who concluded irregularities in the activities of legal entities registered for activities of private security in the form of providing services for their own needs ${ }^{270}$.

Regular supervision over the work of the Chamber and legal persons of private security is done at least once per calendar year. Authorized officials of the Ministry

270 "Handbook for police officers - the role and responsibilities of the police in the performance of control and supervision of legal entities working in private security in accordance with the Law on Private Security", Chamber of the Republic of Macedonia for private security, Skopje 2014, p.5 


\section{Seccurity}

perform the following activities to supervision: 1.determine whether and how to implement this Act and regulations adopted under this Act; 2.check records of contracts under Article 6 (1) of this Act; 3.check business premises, technical facilities and equipment and vehicles used in the pursuit of private security; 4.check the manner of keeping and carrying of firearms, as well as the capability for handling and use of firearms and 5.check the manner of applying the powers of workers for security. If necessary, the authorized officials of the Ministry take other measures and actions for supervision. For activities carried out in legal persons performing private security authorized officials of the Ministry compile a report.

The responsible person in the legal person performing private security or a person authorized by him and the Chamber are obliged to enable the supervision, to make available the relevant documentation and to provide the necessary data and information. If during the supervision determine that the legal person performing private security or the Chamber does not comply with the provisions of this law, the Ministry shall issue a decision to remove the deficiencies within a period not longer than 60 days from the receipt of decision.

Ministry will revoke the license if the legal person performing private security: 1. not anymore eligible for a license according to the provision stipulated in this law and 2. Do not remove the irregularities within the deadline set by the decision. The Ministry informs the Chamber and the Central Registry of the Republic of Macedonia for revocation of the license of legal entity after the finality of the decision.

Ministry will deprive the public authorization of the Chamber established by this law, if not eliminate the deficiencies within the period specified in the decision. In case of depravation of public authorization of the Chamber, public authorization are performed by the Ministry until the removal of shortcomings by the Chamber.

Against the decision to eliminate the shortcomings of the legal entity performing private security that Chamber, the decision to revoke the license for the provision of legal person performing private security and the decision to revoke the public authority of the Chamber, the legal entity or the Chamber are entitled to appeal to the State Commission for administrative procedures and employment in the second instance within 15 days of its submission.

In the event of a violation of legal provisions by legal entities registered for performing activities for securing people and property in the form of provision of services and legal entities registered for performing activities for securing people and 
property for their own needs, as well as by individuals performing work on securing people and property, in order to overcome the stated condition, police is required to undertake the following activities:

$>$ Police officers in the organizational units of the criminal police to plan measures for supervising the operation of legal entities registered to perform an activity for protecting people and property, in terms of respecting the requirements for the provision of persons and property, the fulfillment of their duties and keeping the required records under the Law on private security and surveillance in respect of compliance with the provisions of the Law on weapons in view of the importance of licenses for possession and carrying, storing and keeping of weapons and ammunition, etc.

$>$ Police officers in police stations and police departments to plan measures for supervising the work of individuals that perform the security of persons and property within the legal entities, in terms of respecting their obligations under the Law on Private providing (possession of a license, wearing identification card, wearing work clothes, submitting a written report on the use of force, etc.), and supervision with regard to compliance with the provisions of the Law on weapons (The way of carrying weapons, wearing a license to carry weapons, etc.).

> Commission to implement the procedure for issuing work permit to legal entities for the business of protecting people and property, revocation of license of legal entities for the business of protecting people and property, deprivation of powers of the Chamber of Macedonia to secure people and property, supervising the work of legal entities operating in the security of persons and property, can include other relevant institutions in the supervision (IRS, labor inspectors, etc. 


\section{THE ROLE OF PRIVATE SECURITY IN CRITICAL INFRASTRUCTURE PROTECTION}

\subsection{Origins and development of private security}

The first private security agencies in the country date back to 1994. Within two decades the private security sector is increasingly taking so far traditional police activities related to security and protection. The need of the society to protect itself from rising global threats and crises led to the founding and establishment of this sector for private protection that serves as an extended arm of the police activity in cases where it is impossible to provide constant monitoring, observation and monitoring by police officers of a certain place and a certain time. With the spread of the market, private protection and security in certain segments of life took part of police work, such as providing transportation of money, securing public meetings, sports and cultural events, providing facilities, direct protection of persons and so on.

Great interest in rental services by private agencies nowadays stems from the rise in crime and the lack of resources within the capacity of the national level that are needed to meet the growing demands for protection. Of course, not every agency for private security guards have the same success and the same quality of work, which is due primarily to the reputation or professional image of the same, because it is not easy to gain confidence or belief that the selected agency has a staff capabilities and skills key into potential cases of endangering the safety of the client or his property.

The prevailing opinion that the private security industry is a business expansion due to "high turnover of funds circulating in the industry, the large number of employees that exceeds the total number of police officers, the rapid development of technological development in this area and different and a wide range of commercial security services. ${ }^{\text {"271 }}$

The process of transformation of the state order, the release of the former Yugoslavia, the development of the capitalist economy, the emergence of a growing number of private economic operators and, in particular, emphasized social stratification factors demand additional security services, some of which were (and still

\footnotetext{
${ }^{271}$ Vankovska B. "Security private sector in Macedonia: Between needs and public (non) trust", Skopje, 2016, p.17
} 
are ) of questionable viability and more a kind of presentation of their own prestige or status (specific trend and fad - anyone who can financially withstand that can afford private security guard or bodyguard).

\subsection{Analysis of the legal provisions on private security}

Provisions for protection of people and property were legally regulated by the Law on protection of people and property passed in 1999. Functioning again, the private legal entities that offer security services (supposed to be) contained in the Law on Private Security (Official. Gazette no. 80/99, 66/07 and 51/11). However, it should not overlook the fact that a period of ten years from the adoption of this law, there was no act that determine the specific legal entities, and in this respect the Government adopted the Decision on determining legal entities are required to have collateral of persons and property for their own needs (Fig. Gazette no. 166/10) under the Act, even in December 2010.

Private security is the protection of persons and property is carried out by legal entities that are licensed for private security. Under the Act, private security is an activity of public interest which aims to prevent and detect harmful phenomena and illegal actions that threaten the physical integrity and dignity of the person and property that is protected.

The law regulates the conditions for performing private security, private security for their own needs, mandatory private security powers of private security workers, work clothes and signs of private security workers.

In this context, private security by legal entity can be performed $a s^{272}$ :

1. Security for their own needs based on the license for providing for their own needs, and

2. Security using the services of legal persons performing private security in the form of provision of services, by law, on the basis of an agreement.

Private security for their own needs are carried as physical security, physical protection and monitoring security. "Private security for their own needs may perform legal entity holding a license for private security for their own needs. ${ }^{273 "}$

272 "Law on private security" Official Gazette no. 166/2012, 164/2013, 148/2015, 193/2015, 55/2016, Art.8-10 
Private security in the form of provision of services is carried out as physical and technical security. Physical security in turn, performed as: 1.physical protection 2.monitoring, 3.Ensuring transport and transfer of money and other valuable items and 4.Ensuring public gatherings and other events. ${ }^{274}$ "Private security in the form of provision of services can perform a legal entity that has registration in the Central Register of the Republic and if has a license for private security in the form of provision of services. ${ }^{275 "}$

„Private security may be performed by a person who holds a license and identification card issued by the Chamber. ${ }^{1276}$ Training for physical and technical protection, organized by the Chamber, under the program and performed by the Commission to enable physical security and the Committee on training for technical training is established by the Minister of Interior.

Cooperation between the Ministry of interior and legal entities regarding the provision of expert assistance is of a great importance, so that at the request of the legal person performing private security the Ministry provides expert assistance in organizing private security and conduct training. ${ }^{277}$

Workers employed by private security agencies have the authority to:

1. Perform authentication;

2. Warning of persons to move away from the property that is provided;

3. Not allowing entry of an unauthorized person, and prohibit unauthorized recording or adding equipment for the purpose of the property that provides;

4. Retention and surrender to the police the persons caught committing a criminal offense prosecuted ex officio coming to the police;

5. Inspection of persons, vehicles, and storage, and

6. Use of Force (used if the purpose of treatment cannot be achieved otherwise $)^{278}$.

\footnotetext{
${ }^{273}$ Ibid art.10

${ }^{274} \mathrm{Ibid}$, art.8-10

${ }^{275}$ Ibid, art.10

276 "Law on private security" Official Gazette no. 166/2012, 164/2013, 148/2015, 193/2015, 55/2016, Art. 20

277 Ibid art.26

${ }^{278}$ Ibid art.45
} 
Legal entities who work on private security activities in the form of provision of services and legal entities that perform private security for their own needs come together in the Chamber of the Republic of Macedonia for private security. They join for the purposes of protection and promotion of expertise, professionalism and dealings and to protect the profession to join the Chamber. ${ }^{279}$

\section{CONCLUSION}

From the elaboration above it is evident that despite the fact that in our country we are working on improving the protection of critical infrastructure by the police and by the Chamber of private security, there are a number of steps, measures and activities in the process of providing safety to critical capabilities that have yet to be implemented or if they are in progress to be elevated to a higher level.

In order to improve the protection of critical infrastructure the following is of utmost importance:

First, to emphasize the importance of measures and activities for providing facilities to be planned and undertaken based on communication, dialogue and mutual trust between the entities responsible for the protection of critical infrastructure.

Second, to establish standards for the planning of measures and activities in all stages of the protection of facilities (prevention, management and recovery), and preparing a list of critical infrastructure in the interest of the state.

Third, the creation of appropriate national security concept to protect critical infrastructure, which will provide a coordinated approach to all subjects, with explicit division of roles and responsibilities in the provision of critical infrastructure.

Fourth, to strengthen the level of protection of objects is necessary to continuously strengthen the capacities of entities responsible for the protection of critical infrastructure, in terms of training, equipment, monitoring and evaluation, exchange of information, planning, coordination and monitoring of measures .

Fifth, the continuous strengthening of the capacities of the Ministry of Interior for supervising the work of the Chamber and legal persons registered for private business secured by providing services for their own needs.

${ }^{279}$ Ibid art.59 
Sixth, establish and improve legislation in this area and harmonization of laws and regulations with European legislation and regulations.

From the above we can rightly conclude that the protection of critical infrastructure must be based on systematic education, training, optimum use of resources, planning and effective implementation of the necessary measures and activities by the entities responsible for the protection of critical infrastructure.

\section{LITERATURE}

1. "Police Law", Official Gazette no. 114/06

2. "Law on private security" Official Gazette no. Published in the Official Gazette number: 166/2012, 164/2013, 148/2015, 193/2015, 55/2016

3. „National Concept for Security and Defense," Official Gazette of RM no. 40/03

4. "Legal framework for the provision of critical infrastructure, with a view to providing it of critical infrastructure in the country," Macedonian Chamber of private security Skopje, 2016

5. "Handbook for police officers - the role and responsibilities of the police in the performance of control and supervision of legal entities working in private security pursuant to the Private security" Chamber of the Republic of Macedonia for private security, Skopje 2014

6. "Decree on the people and the facilities provided, the types of measures and activities and levels of security", Official Gazette no. 56/14

7. Critical Infrastructure Security and Protection, The Public-Private Opportunity, White Paper and Guidelines by CoESS, December 2010, str.5

8. Vankovska B. "The private security sector in the country: between the needs and the public (in) trust," Chamber of the Republic of Macedonia on Private Security, Skopje, 2016

9. Mitrevska M. "Crisis Management", Faculty of Philosophy, Skopje, 2015 (new edition)

10. NATO Workshop in Brussels, "Development plans for inter-institutional exchange of information security in the country", 2011-04-09, http://mail.cuk.gov.mk/index.php?arhiva $=1 \&$ content $=354$, accessed on 25.01.2016 year. 